\title{
IDH1/2 Mutation Analysis Testing Method
}

National Cancer Institute

\section{Source}

National Cancer Institute. IDH1/2 Mutation Analysis Testing Method. NCI Thesaurus. Code C158887.

A request to enter the specific molecular analysis method used to detect and identify mutations in the genes IDH 1 and IDH2. 